\title{
After Beckett: The Influence of Samuel Beckett on the Fiction of J. G. Farrell
}

The presence of Malcolm Lowry and Vladimir Nabokov in J. G. Farrell's writing has been observed by many critics, and meticulously documented by Chris Ackerley in his essay "A Fox in the Dongeon: the Presence of Malcolm Lowry in the Early Fiction of J. G. Farrell." Ackerley's sagacious title also recognizes the echoes of Richard Hughes that reverberate through Farrell's fiction. ${ }^{1}$ Ackerley notes also that 'the ghost of Samuel Beckett may be felt throughout Farrell's early work, but less as a conscious identity than as a brooding implicit presence." 2 Yet the influence of Beckett on Farrell's work remains ill defined. Looking back over my own work on Farrell—particularly the book I coauthored with Jennifer Livett, Troubled Pleasures: The Fiction of J.G. Farrell (1991)—it is interesting to see how often Beckett's name appears. Farrell was well aware of the shadowy allusions to Beckett that punctuate his early work, and consequently, what I aim to do here is map the shadowy presence of Beckett's fathering hand in Farrell's fiction and, in doing so, consider why he drew on Beckett.

Setting aside their obvious literary talent for the moment, detectable links between Farrell and Beckett include their early athletic prowess-primarily tennis and cricket in Beckett's case, but also rugby; rugby in Farrell's case, but also cricket and tennis-and what Lavinia Greacen has referred to as their shared sense of "claustrophobia in comfortable middle-class Protestant Dublin." 3 This sense of claustrophobia that caused Farrell-like Wilde, Joyce, and Beckett before him—-to leave Ireland after a year teaching in a prep school

1. Farrell met and admired Hughes, and consequently there are numerous traces of Richard Hughes's work in Farrell's fiction. Farrell recalls having read Hughes's In Hazard (1938) as a child. Allusions to The Fox in the Attic (1961) occur in both The Lung and A Girl in the Head, and The Singapore Grip contains a veiled reference to A High Wind in Jamaica (1929).

2. Chris Ackerley, "A Fox in the Dongeon: the Presence of Malcolm Lowry in the Early Fiction of J. G. Farrell," in J. G. Farrell: The Critical Grip, ed. Ralph J. Crane (Dublin: Four Courts Press, 1999), p. 25 .

3. Lavinia Greacen to Ralph J. Crane, 14 August 2002. 
in Dublin. As in Beckett's case, Farrell's "separation from Ireland," according to Bridget O'Toole, "was crucial to the novelist."4 Their lives intersect in other ways too. Beckett played tennis at Carrickmines Tennis Club, where Farrell often went a generation later. Beckett also played golf at Greystones, where Farrell's father frequently played. Both Beckett and Farrell often walked in the Dublin mountains, both were the sons of businessmen, and neither was classically Anglo-Irish (in terms of a landed gentry fatally hitched to the English social round but distanced from it by Irish perceptions). In exile, both remained influenced by their Protestant conscience as shown by their self-discipline, austerity, and sense of personal responsibility. Both, of course, were Irishmen who escaped to France. Unlike Beckett, Farrell did not stay there, but he did remain a lifelong Francophile. Both, incidentally, drank at O'Neill's pub when in Dublin.

Crucially, in respect to the presence of Beckett in Farrell's fiction, we know for certain that Farrell read and was a great admirer of Beckett's work. Returning to Oxford after recovering from polio, Farrell was gripped by Malone Dies (1956). He talked about it, he read it obsessively, and he recommended it to such friends as Brian Knox Peebles. Then, in 1966, Farrell took up a Harkness Fellowship at Yale University. The move to America was not an easy one for Farrell. In her biography, Lavinia Greacen describes his loneliness in New Haven, which was "sharpened when he went to see Beckett's Endgame performed by the touring Theatre of Living Arts, in which Hamm and Clov were played as Laurel and Hardy—billed as a vaudeville production — and mimed a masturbatory sequence."5 "Back in his quiet room," Greacen tells us, "Jim was haunted by Beckett's lines, which he knew almost by heart." 6

Although the influence of Beckett's pessimistic late modernism is, in hindsight, clearly evident in Farrell's first novel The Man From Elsewhere (1963), the first reviewer to bring Samuel Beckett into Farrell criticism was Bernard Share, the founding editor of Books Ireland, in his Irish Times review of Farrell's second novel, The Lung (1965). Share does not suggest a straightforward influence, but nevertheless makes the connection for the first time: "Farrell forestalls any easy comparison with Beckett or other chroniclers of the self-obsessed."

Farrell's next novel A Girl in the Head (1967), is, as Chris Ackerley has shown, heavily influenced by both Malcolm Lowry's Under the Volcano (1947) and Vladimir Nabokov's Pale Fire (1962). Farrell's third novel also plainly reveals "the

4. Bridget O’Toole, "Not a Crumb, Not a Wrinkle: J. G. Farrell at Work," Irish Studies Review, 12 (1995), 28.

5. Lavinia Greacen, J. G. Farrell: The Making of a Writer (London: Bloomsbury, 1999), p. 208.

6. Greacen, p. 212.

7. Bernard Share, "Respiratory Tract," rev. of The Lung, Irish Times, 30 October 1965, p. 11. 
fathering hand of Beckett," as a number of reviewers observed. In his review for the Listener, Ian Hamilton saw the connection in terms of pastiche:

Mr Farrell is witty and intelligent and he manages Boris's specific grumbles with fine pessimistic flair; it is when he tries to extend his hero's misery beyond the confines of the immediate mess he's in that a certain flabbiness reveals itself. There is a bid for that stately, emblematic decrepitude which universalizes Beckett's deadbeats but it never gets beyond adroit pastiche. ${ }^{8}$

The anonymous reviewer for the Times Literary Supplement is less sure of Beckett's influence:

It needs a good deal of poise to prevent Boris from becoming tiresome. He takes after fashionable literary personae (the fathering hand of Beckett has been suggested, but Boris's tone is really closer in its aggressive fastidiousness to some of Nabokov's elderly and disaffected cosmopolitans). ${ }^{9}$

Two years later, Barry Baldwin, writing in the Library Journal, suggests

The atmosphere is redolent of Pinter's Birthday Party, in a subfusc way, and is eked out by having the central character spend the time between drink and copulation moaning into a tape recorder after the manner of Beckett's Krapp's Last Tape (lest we miss the point, these passages are printed in italic script with the words sometimes straggling up and down the page). ${ }^{10}$

Since then various critics have noted the presence of Beckett, particularly in the early fiction. Prabhu S. Guptara, for example, has suggested that "J. G. Farrell's rich and densely patterned comic style has familial links with other exiles such as Nabokov and Beckett." 11 Ronald Binns, an early champion of Farrell's fiction, acknowledges that "technically A Girl in the Head is Farrell's most experimental work," but feels that it “doesn't quite come off: one senses (perhaps wrongly) a variety of undigested influences_Camus, Beckett, Lowry." 12

Few reviewers or critics have seen "the fathering hand of Beckett" in Farrell's later works, and no one has yet teased out the presence of Beckett in Farrell's fiction in the way that critics like Ronald Binns and Chris Ackerley have discerned the presence of Lowry and Nabokov in his work. Beckett is a rather more subtle

8. Ian Hamilton, "Fiction: Comfortably Surreal," rev. of A Girl in the Head, Listener, 3 July 1967, p. 23 .

9. "At the End of the Line," rev. of A Girl in the Head, Times Literary Supplement, 20 July 1967, p. 644 .

10. Barry Baldwin, rev. of A Girl in the Head, Library Journal, 94 (1969), 2485.

11. Prabhu S. Guptara, “J. G. Farrell," in Contemporary Novelists, ed. James Vinson, (London:

St. James Press, 1982), p.728.

12. Ronald Binns, "The Fiction of J. G. Farrell," Malcolm Lowry Newsletter, 5 (1979), 23. 
presence in Farrell's fiction than is Camus in A Man From Elsewhere, or Lowry and Nabokov in A Girl in the Head.

The farcical, tragic-comic attempts of Murphy, Malloy, Malone, and Moran to cope with life echo through all Farrell's six completed novels, yet it is hard to pinpoint specific allusions to any of these characters. Farrell includes Beckett in his writing in two distinct ways. First there are a few deliberate and clearly identifiable allusions to Beckett's work. And then, and of far more significance, there are liberal traces of Beckett that are more often felt than seen in Farrell's work - the "fathering hand" referred to earlier. As Chris Ackerley has shown in his discussion of the presence of Lowry and Nabokov in Farrell's fiction, this is about tone. Beckett's presence in Farrell's work, then, is less an "intertextual" one in the Kristevan sense, than a brooding implicit presence that only occasionally manifests itself as a deliberate allusion.

Beckett's completed trilogy-Molloy, Malone Dies, and The Unnamablewas first published in English in 1959. The bleakness and absurdity of life is played out in Farrell's early novels in characters whose names begin with the letter $\mathrm{M}$, the letter that appears at irregular intervals throughout Beckett's fiction. In Farrell's first three novels we find: Mado, Marie-France, Monique in A Man From Elsewhere (1963); Martin, Marigold, Monica, Michael, Max, Exmoore (whose real name is Moore) in The Lung (1965); and Melanie, Marie-Thé, Maurice, and Mick (Slattery) in A Girl in the Head. Moreover, the letter M falls from the wall of the Majestic Hotel and crashes on to the tea table in Troubles (1970), where we also find characters named Murphy and the Major. The Major later reappears in The Singapore Grip (1978) alongside Matthew, Monty, and McMahon.

More obvious still are the names of the three pigs in Troubles-Johnston, Mooney, and O'Brien-which function as a specific allusion to Beckett's story "A Wet Night" in which the drunken Belacqua, "Feeling suddenly white and clammy ... leaned against the iron wicket set in the College wall and looked at Johnston, Mooney and O'Brien's clocks." 13 Johnston, Mooney and O'Brien "was a popular bakery and confectionary shop on Leinster Street that sported a fine pair of clocks." 14

The traces of Beckett that are felt rather than seen in Farrell's fiction are more abundant and much richer. In A Man from Elsewhere, Regan "haul[s] himself in to the future with numb and bleeding fingers," and thus displays the

13. J. G. Farrell, Troubles (1970; London: Phoenix, 1993), p. 145. Samuel Beckett, "A Wet Night," in More Pricks Than Kicks (1934; London: Calder and Boyars, 1970), p. 75. I thank Greg Murray, Otago University, for drawing my attention to this allusion.

14. James Farrell [J. G. Farrell], A Man from Elsewhere (London: New Authors, 1963), p. 110; hereafter cite parenthetically, thus: (ME 110). 
Beckettian heroism summed up in the oft-quoted final words of Beckett's trilogy, "I can't go on, I'll go on."15 In the same novel Audin's axe-chopping takes on a Godot-like repetition. Heroism in Farrell's world is, as in Beckett's, the courage to face whatever is. In A Man from Elsewhere flashes of bizarre humor also point to Beckett. In the early pages of the novel Sayer watches from the window as an old woman stops to exchange words with an old man walking a dog. He thinks that "[c] onsidering the speed of [the earth's] revolution, the old man and the woman were doing very well to keep their balance. The dog was standing squarely on four legs and so deserved less credit" (ME 15-16). Farrell's debt to Beckett is obscured in A Man from Elsewhere because he adopts what appears to be a realist style and a plot with more straightforward development than the disorienting, unfathomable proceedings of Molloy, Malone Dies, and The Unnamable.

Farrell's second novel, The Lung, though still realist at the start, moves closer to a kind of theater of the absurd as it continues. The displacement that Martin Sands undergoes in this novel is not merely geographical, but involves a state of being, from health (perhaps) to sickness, though the whole tenor of the work implies fundamental questions about "normal" health and sanity. There is, as well, a Beckettian influence in Farrell's use of italics in The Lung. ${ }^{16}$ The italics temporarily shift the narrative to the present tense, and, like the fictional story Martin is writing about "Max," form a metanarrative of their own. These italic passages are clearly intended to read like stage directions and to suggest that, like the events in a stage play, life is a carefully directed, predetermined drama. These stage directions describe a hospital room where, lying in his iron lung, Martin Sands "is in a light feverish sleep." On the wall above the bed,

is a framed picture he has not yet seen. It is a print of "The Young Raleigh," showing a small boy sitting on his heels, arms clasped round his knees, and listening spellbound to an old seaman who, right arm outstretched, is pointing towards the horizon.

The print of 'The Young Raleigh' shows Raleigh's life being "pointed out" for him by the fisherman's outstretched arm. This emphasizes an idea of life in which determinism and contingency together defeat any willed human choice. The whole thing is futile in Martin's view, as a particularly Beckettian exchange with Nurse Phelps suggests:

"Nurse, has it ever occurred to you that we are all just waiting for a tragedy to happen ... like the death of the people we love or our own death ..."

15. Three Novels by Samuel Beckett: Molloy, Malone Dies, TheUnnamable (New York: Grove Press, 1981), p. 414.

16. James Farrell [J. G. Farrell], The Lung (London: Hutchinson, 1965, pp. 50, 65; hereafter cited parenthetically, thus: $(L 50,65)$. 
"You are cheerful. I don't know why you don't just die and get it over with and give us all a rest."

"... and that it doesn't make any real difference whether this tragedy happens tomorrow or in twenty years time since there's no avoiding it ..."

"A real Mr. Sunshine, aren't you?"

“. . . and that everything we do, absolutely everything, whether it's playing marbles or being the Prime Minister, is just a way of passing the time till it happens ... even the things we enjoy like going to the cinema or making love..."

And the affirmation of life in the last few lines of the novel is equivocal, guarded, and very reminiscent of Beckett: "Perhaps. No. Yes. Perhaps.” The Lung also begins to reveal Farrell's gift for a bizarre and often grim humor that seems to combine Beckett with "The Goon Show."

Martin Sands, confined in his iron lung, further, exhibits a state of being like that of Beckett's Murphy, who seems to enact a Cartesian split into mind and body, eventually becoming half man, half rocking-chair. Hugh Kenner sees Beckett's "Cartesian Centaurs" as half man, half bicycle, and Sands, too, becomes half man, half machine as the lung breathes for him. ${ }^{17}$ But Kenner's ego-cyclistical Centaur refers only to the earlier Beckett heroes for whom motion is still possible. Farrell's Sands resembles better Beckett's Winnie in Happy Days (1961), buried first to the waist and then up to the neck, or Hamm in his chair and Nagg and Nell in their dustbins in Endgame (1958).

The slapstick and burlesque of other scenes in The Lung is a reminder that the context of early Beckett is also that of Charlie Chaplin. During his convalescence Sands, standing in the lavatory of the village pub, reads a question in the graffiti on the walls. This question, like most of the questions in Sands's life, has no answer:

The question seemed to be rhetorical. Disappointed he pulled the swing door and stood on the threshold of the lounge. For a terrible moment he thought the others must have left. The swing door, forgotten, swung and hitting him a solid blow in the back, dropped him. He lay on the dirty floor beside an empty cigarette packet and a half nibbled meat pie. For the sake of appearances he groaned. Actually he was feeling quite comfortable. The ceiling was yellowish and innocent of jokes, most restful to the eye.

Similar moments persist in Farrell's fiction through his last completed novel The Singapore Grip (1978), where, for example, Matthew "attempting to

17. See Hugh Kenner, "The Cartesian Centaur," in Samuel Beckett: A Critical Study (1961; Berkeley: University of California Press, 1973), pp. 117-32. 
demonstrate to the Doctor the width of a stream where he had once caught a number of trout, struck Mrs Blackett a blow in the stomach that robbed her of breath." 18

Waiting symbolizes the human condition, as Farrell had shown in The Lung, even if the awaited one in his next novel, A Girl in the Head, is not Beckett's $\operatorname{God}(\mathrm{ot})$ but, suitably for the late 1960 s, a fantasized female representing idealized sexual desire. A Girl in the Head differs from Farrell's two earlier novels in having the comic as its dominant mode. Even so, an accompanying sense of the tragic does arise, as in Beckett, out of the absurd disparity between the grandiose philosophical and literary ideas humans have about humanity, and the insignificant thing humanity turns out to be when viewed through science and eternity.

The title of A Girl in the Head obviously points to Nabokov's Lolita (1955), which, as Ronald Binns puts it, is "the classic account of a 'girl in the head,"'19 yet the cover of the 1969 Pan paperback edition of Farrell's novel, which shows Farrell buried up to his neck in sand beside a girl clad in a red bikini, and, thus, nods toward Winnie in Beckett's Happy Days and, through her, to Beckett's other motionless heroes. And, as Chris Ackerley has pointed out, "Boris's frantic ride on the rusty bicycle takes him to the heart of the Beckett country." 20

There are few explicit traces of Beckett—or Lowry or Nabokov-to pursue in Farrell's later work. Farrell turned away from Beckett as he increasingly regarded his early novels as unsatisfactory-to the point of dropping A Man From Elsewhere from the list in his last novel The Singapore Grip, though more recent posthumous editions have restored the title. According to George Brock, Farrell came to see his first three novels as "casting around." 21 In an interview with Malcom Dean, published in the Guardian shortly after the publication of his Booker Prize-winning novel The Siege of Krishnapur (1973), Farrell turned on Beckett, whose hand had influenced his "casting around." He dismissed "those rather uninteresting mechanical feats, like writing a novel all in one sentence," in a scarcely disguised attack on Beckett's Comment c'est $(1961) .^{22}$

Nevertheless, those early novels were the prelude to his magnificent later fictions, commonly referred to as his "Empire trilogy." The influence of writers like

18. J. G. Farrell, The Singapore Grip (1978; London: Phoenix, 1992), p. 128.

19. Ronald Binns, J. G. Farrell (London: Methuen, 1986), p. 42.

20. Ackerley, p. 29. J. G. Farrell, A Girl in the Head (1967; London: Fontana, 1981), p. 179.

21. George Brock, "Epitaph for Empire," rev. of The Singapore Grip, Observer Magazine, 24 September 1978, p. 73 .

22. Malcolm Dean, “An Insight Job," rev. of The Siege of Krishnapur, Guardian, 1 September 1973, p. 11. 
Beckett had helped make Farrell one of the most accomplished novelists of his generation. In turn, the "fathering hand" of Farrell can be found in the work of such writers as Timothy Mo, Giles Foden, and Matthew Kneale, who all readily acknowledge Farrell as an influence. Thus, by way of Farrell, the ghost of Samuel Beckett becomes an inescapable, unwilled, inadvertent, intertextual presence in the work of those writers.

UNIVERSITY OF TASMANIA

\section{Clúdach: Cover}

Our covers on the ninth volume of New Hibernia Review will present a selection of stained glass from a range of artists and periods. We begin here with a detail from what may well be the most extraordinary exemplar of stained glass in Irish ecclesiastical art, the Harry Clarke windows of the Honan Chapel (properly, the Chapel of St. Finn Barr) on the campus of University College Cork. Consecrated in 1916, the Honan Chapel displays in its architecture and its decoration every element of the Irish arts and crafts movement. Its furnishings, textiles, vestments, and its stained glass were executed at the height of the early twentiethcentury Celtic Revival, of which the illustrator Harry Clarke (1889-1931) was among the most accomplished artists. Five of the chapel's windows were executed by Clarke. Born in Dublin, and educated in London and at the Dublin Art School, Clarke began working in stained glass as early as 1910. His work in this medium is distinguished by its sumptuous color and by its seamless blending of Symbolist, Art Nouveau, and medieval influences.

The detail here is from the chapel's sixth window, dedicated to St Finbarr (d. 623), the patron saint of Cork. Because of Finbarr's reputed educational activities at an Early Christian monastic site just east of the university's main campus, he is also patron of the university; the motto of UCC is "Where Finbarr Taught, Let Munster Learn." He is traditionally shown with his attribute of a glowing right hand, which according to his legend was caused by being touched by Christ, and which Finbarr thereafter always covered with a glove.

The editors thank University College Cork, and especially the university curator, Michael Holland, for its kind assistance in presenting this photograph to the readers of New Hibernia Review. The copyright on this image, and all of the chapel's works, is held by the Honan Trust, and we likewise thank the Trust, and in particular Fr. Joseph Coghlan, chaplain, for generous permission to reproduce this picture here. In March, 2005, Cork University Press published The Honan Chapel: A Golden Vision, edited by Virginia Teehan and Elizabeth Wincott Heckett, which provides a splendid account of this masterpiece of Irish church architecture. 